Article

\title{
Antifibrotic Activity and In Ovo Toxicity Study of Liver-Targeted Curcumin-Gold Nanoparticle
}

\author{
Amirah Adlia ${ }^{1, * \mathbb{D}}$, Ilham Tomagola ${ }^{1,2,+}$, Sophi Damayanti ${ }^{1}$, Ardyanto Mulya ${ }^{1}$ \\ and Heni Rachmawati ${ }^{1}$ \\ 1 School of Pharmacy, Bandung Institute of Technology, Bandung 40132, Indonesia; \\ ilham_azadiracta89@ymail.com (I.T.); sophi.damayanti@fa.itb.ac.id (S.D.); ardiyanto_mulya@me.com (A.M.); \\ h_rachmawati@fa.itb.ac.id (H.R.) \\ 2 Faculty of Pharmacy, Universitas Muslim Indonesia, Makassar 90231, Indonesia \\ * Correspondence: amirah@fa.itb.ac.id; Tel.: +62-819-688-711 \\ † Deceased 15 July 2018.
}

Received: 4 August 2018; Accepted: 7 September 2018; Published: 21 September 2018

\begin{abstract}
Conjugation of curcumin and gold with green chemistry is an approach to improve the effectiveness of curcumin as anti-fibrosis. In this work, curcumin and gold were conjugated to deliver curcumin to the liver. Curcumin-gold nanoparticles (cAuNPs) were prepared by varying curcumin $\mathrm{pH}$ and concentration. The successful of cAuNPs formation were identified by using UV-visible and FTIR spectrophotometers. The particle size and morphology were analyzed using particle size analyzer and cryo-TEM respectively. In vitro antioxidant assay was performed to determine the curcumin activity after conjugation. Physical and chemical stabilities of cAuNPs were studied for one month at $5{ }^{\circ} \mathrm{C}, 25^{\circ} \mathrm{C}$, and $40^{\circ} \mathrm{C}$. Furthermore, the cAuNPs activity to modulate early marker of fibrosis was tested on NIH/3T3 cells. The optimum condition for cAuNPs synthesis was by using $1.5 \mathrm{mM}$ curcumin at $\mathrm{pH}$ 9.3. As compared to free curcumin, cAuNPs showed higher antioxidant activity and maintained the nanosize after stored for one month. In line with the antioxidant activity, cAuNPs $0.25-1 \mu \mathrm{g} / \mathrm{mL}$ reduced the collagen production by NIH/3T3 cells. More importantly, cAuNPs did not demonstrate any effect on the development of chicken embryo. Taken together, the attachment of gold to curcumin in the form of cAuNPs is promising for curcumin targeting to treat hepatic fibrosis.
\end{abstract}

Keywords: curcumin; curcumin-gold nanoparticle; liver fibrosis; NIH/3T3; in ovo

\section{Introduction}

Liver is the principal site of metabolism, which processes and cleans toxic compounds from the body. Therefore, damage in the liver due to various factors has serious effect that potentially cost a person's life. Chronic hepatic disease is still an unresolved issue in many countries [1-3]. Hepatitis $\mathrm{B}$ or $\mathrm{C}$ viral infection, excessive alcohol and particular drugs consumption, and non-alcoholic fatty liver disease are the main factors that lead to chronic hepatic disease [1,4-6]. To date, there is no effective treatment yet for chronic hepatic disease. The recent direct antiviral agent to treat hepatitis is not affordable for most hepatitis patients in the world [7,8]. Nevertheless, the research in the use of natural products as an adjuvant and alternative medicine for hepatitis infection, liver fibrosis, cirrhosis, and cancer has been widely reported in the recent years [9-11]. Liver fibrosis is one of the chronic diseases that requires long-term treatment, so the use of scientifically proven safe and effective natural products is being investigated extensively by medical researchers and pharmaceutical industries $[9,12,13]$. 
In the previous work, our group has successfully developed nanocarrier based curcumin and silymarin [14]. Both natural compounds were suggested to have synergism effect in the in vitro model of liver fibrosis. The co-encapsulation of curcumin and silymarin in nanoemulsion enhanced their activities, which was indicated by the reduction of collagen type IV expression in mouse and NIH/3T3 cell line at gene as well as protein levels [14]. In agreement with our results, other reports also described the potential use of curcumin as an antifibrotic agent, which have been shown in different animal models of liver fibrosis [15-18]. Nevertheless, the developed curcumin nanoemulsion has a relatively low distribution to the liver. Therefore, a targeted system is required to increase the delivery of curcumin specifically to hepatic compartment. In this report, we described the conjugation of curcumin to gold to produce nanoparticles with an aim to use the curcumin-gold nanoparticles (cAuNPs) as a theranostic nanomedicine.

cAuNPs were synthesized with green nanotechnology concept, which means that the used materials and production steps were safe and non-toxic. Green nanotechnology was developed to overcome the drawbacks of conventional chemical method that utilized toxic reductive and capping agents, such as sodium citrate, sodium borohydride, and sodium dodecyl sulfate [19]. In biological or green chemistry, the biological organisms are used to synthesize metal nanoparticles. Some plants have been used in the biosynthesis of gold nanoparticle, for instance, lemongrass, tamarind, and curcumin $[19,20]$.

Gold particles (10-250 nm) have been shown to accumulate only in the liver and spleen [21]. Gold accumulation and metabolism are affected by the particle size, surface characteristic, dose, and administration route [22,23]. Since gold nanoparticles are mostly distributed in the liver, these particles can be used to direct curcumin to the liver. Several approaches have been done in conjugating curcumin to gold nanoparticles. Manju conjugated gold nanoparticle to water soluble curcumin, which was obtained from conjugation of curcumin to hyaluronic acid [24]. Another approach was done by enhancing curcumin solubility with high temperature [25]. A one-step synthesis of curcumin gold nanoparticle was performed by Sindhu et al. [26] at low temperature and the $\mathrm{pH}$ of curcumin solution was increased while using $\mathrm{K}_{2} \mathrm{CO}_{3}$. Nevertheless, Sindhu et al. [26] used DMSO as curcumin solvent, which can be toxic for hepatic cells. Toxicity issue is important in the treatment liver fibrosis because cell death can lead to liver damage, which eventually cause more fibrotic tissue. In our study, we used $\mathrm{NaOH}$ solution to dissolve curcumin [27]. It has been shown that curcumin solubility is slightly improved at basic condition [28]. Sreelakshmi et al. [29] used $\mathrm{NaOH}$ to dissolve curcumin, but the $\mathrm{pH}$ of the final solution was not known. Thus, we varied the $\mathrm{pH}$ of curcumin solution in this study to find the optimum condition for curcumin gold conjugation.

Although the successful conjugation and biological activity of cAuNPs has been shown in several studies, there is no study yet showing their effect on fibrosis. Besides, all of the toxicity studies on cAuNPs were conducted at the cellular level, which might not relate with its in vivo effect $[19,24,29-31]$. In this study, we perform an in ovo toxicity test of cAuNPs. In ovo culture of fertilized eggs is a valuable method for the study of chicken development, egg manipulation, and toxicity [32]. In ovo has a more complex biological environment when compared to cell line. Hence, it reflects more closely to the in vivo situation.

\section{Materials and Methods}

\subsection{Materials}

Curcumin (PT. Phytochemindo Reksa, Bogor, Indonesia), Gold (III) chloride $\left(\mathrm{AuHCl}_{4}\right)$ (Sigma-Aldrich, St. Louis, MO, USA), sodium hydroxide, dimethyl sulfoxide pro analysis (Merck, Darmstadt, Germany), Ethanol absolute (Merck), NIH/3T3 cell from American Type Culture Collection $\left(\right.$ ATCC $^{\circledR}$ ) (DLBS PT. Dexa Medica, Bekasi, Indonesia), fetal bovine serum (FBS, Gibco ${ }^{\circledR}$, Carlsbad, CA, USA), Dulbecco's Modified Eagle Medium (DMEM, Gibco $\left.{ }^{\circledR}\right)$, Penicillin-Streptomycin $\left(\right.$ Gibco $\left.^{\circledR}\right)$, Trypsin-EDTA $\left(\right.$ Gibco $\left.^{\circledR}\right)$, Sirius Red/Fast Green Staining Collagen (Chondrex, Redmond, WA, USA), 
fertilized chicken eggs (PT. Lestari Farm, Sragen, Indonesia), distilled water (IPHA Laboratories, Bandung, Indonesia), aquabidest (Ikapharmindo Putramas, Jakarta, Indonesia), acetonitrile pro HPLC (Merck), ethyl acetate (Brataco, Jakarta, Indonesia), ascorbic acid, Phosphate Buffer Saline (PBS) pH 7.4, and 1,1-diphenyl-2-picrylhydrazyl (DPPH) (Sigma-Aldrich).

\subsection{Methods}

cAuNPs Synthesis

cAuNPs were prepared by varying the $\mathrm{pH}$ of curcumin solution and curcumin concentration. Curcumin $(0.01 \mathrm{mmol})$ was dissolved in $2 \mathrm{~mL}$ of $10 \mathrm{mM} \mathrm{NaOH}$, and the volume was made up to $10 \mathrm{~mL}$ with distilled water. The $\mathrm{pH}$ of curcumin solution was adjusted by varying the concentration of $\mathrm{NaOH}$. To synthesize cAuNPs, $1 \mathrm{~mL}$ of $1 \mathrm{mM} \mathrm{AuHCl}_{4}$ was added to $8 \mathrm{~mL}$ of distilled water. The solution was added dropwise to $1 \mathrm{~mL}$ of freshly prepared curcumin solution with different concentrations, i.e., 0.25 ; $0.5 ; 0.75 ; 1 ; 1.5 ;$ and, $2 \mathrm{mM}$. The $\mathrm{AuHCl}_{4}$ was added within 2 min of adjusting curcumin $\mathrm{pH}$ to avoid curcumin degradation [26]. The mixture was allowed to stir at $1000 \mathrm{rpm}$ for $2 \mathrm{~h}$.

The purification procedure was adopted from Sindhu et al. [26] with a slight modification. First, the mixture was kept at room temperature for two days and centrifuged at 10,000 rpm for $15 \mathrm{~min}$. To remove the unreacted curcumin and $\mathrm{AuHCl}_{4}$, the obtained pellet was resuspended in distilled water and centrifuged at the same speed. Lastly, the pellet was resuspended in distilled water and was used for further characterizations.

\subsection{Determination of Curcumin in cAuNPs}

The concentration of cAuNPs in the mixture was determined by measuring the curcumin concentration with Waters HPLC (Milford, MA, USA). Sample of $200 \mu \mathrm{L}$ was diluted with $100 \mu \mathrm{L}$ aquabidest. Then, $3.5 \mathrm{~mL}$ of ethyl acetate was added to the solution and mixed with vortex for $30 \mathrm{~s}$. The mixture was extracted by using roller mixer for $30 \mathrm{~min}$ and followed by centrifugation at $5000 \mathrm{rpm}$ for $5 \mathrm{~min}$. Afterwards, $3 \mathrm{~mL}$ of the organic phase was separated from the mixture and evaporated to dryness under a gentle stream of nitrogen at $37^{\circ} \mathrm{C}$. The residue was reconstituted with $200 \mu \mathrm{L}$ of acetonitrile:water (1:1) and then mixed with vortex for $1 \mathrm{~min}$. The curcumin content was analyzed by using HPLC with UV detector at $425 \mathrm{~nm}$. Analysis was performed on an RP 18 column $(150 \times 3.9 \mathrm{~mm}$, $5 \mu \mathrm{m}$ particle size, Waters) with $50 \mu \mathrm{L}$ of sample, and the mobile phase was linear gradient of $55 \%$ acetonitrile in phosphate buffer $\mathrm{pH} 4.5$ at a flow rate of $1 \mathrm{~mL} / \mathrm{min}$.

\subsection{UV-Visible Spectrophotometry}

The formation of cAuNPs was analyzed by using UV-Vis spectrophotometry (Beckman Coulter, Brea, CA, USA). The spectra of curcumin and cAuNPs were recorded over the wavelength range from 400 to $700 \mathrm{~nm}$.

\subsection{Particle Size}

Particle sizes of cAuNPs were measured by using Photon Correlation Spectroscopy (Delsa ${ }^{\mathrm{TM}}$ Nano C Particle Analyzer, Beckman Coulter).

\subsection{Fourier-Transform Infrared (FTIR) Spectroscopy}

Prior to the FTIR analysis, cAuNPs solution was lyophilized while using freeze-drying technique. The dried samples were mixed with $\mathrm{KBr}$ to obtain pellets, and the measurements were carried out in the range from 4000 to $400 \mathrm{~cm}^{-1}$.

\subsection{Morphology of cAuNPs}

Morphology of cAuNPs was analyzed by using cryo-Transmission Electron Microscopy (TEM HT7700 low voltage, Hitachi, Tokyo, Japan). Sample was dripped over carbon plate coated with copper, and the plate was dried in UV-vacuum for $1 \mathrm{~h}$ prior to sample shooting. 


\subsection{Antioxidant Activity Assay of cAuNPs}

The antioxidant activity of the sample was measured according to the procedure that was described by Blois [33]. Methanolic solution of cAuNPs ( 1 to $5 \mu \mathrm{g} / \mathrm{mL})$ was added separately to $1 \mathrm{~mL}$ of methanolic solution of $0.1 \mathrm{mM} \mathrm{DPPH}$ and allowed to stand for $30 \mathrm{~min}$ at room temperature. After incubation, the absorbance of each solution was determined at $517 \mathrm{~nm}$ by using spectrophotometer. Ascorbic acid was used as standard.

The $50 \%$ inhibitory concentration $\left(\mathrm{IC}_{50}\right)$ was calculated from dose response curve obtained by plotting percentage inhibition versus concentration.

$$
\text { Inhibition }(\%)=\frac{(\text { Absorbance of control }- \text { Absorbance of test sample })}{\text { Absorbance of control }} \times 100
$$

\subsection{Stability Testing of Curcumin-Gold Nanoparticl}

A short-term stability testing of nanoparticles was performed to determine the physical and chemical stability of the nanoparticles. Samples were placed in the vials and stored at different temperatures $\left(5^{\circ} \mathrm{C}, 25^{\circ} \mathrm{C}\right.$, and $40{ }^{\circ} \mathrm{C}$ ) for one month. The sampling was done on days 0 (day of manufacture), 1, 3, 6, 9, 15 and 30. The sample analysis included particle size by using Photon Correlation Spectroscopy (Delsa ${ }^{\mathrm{TM}}$ Nano C Particle Analyzer, Beckman Coulter), and measurement of curcumin concentration in cAuNPs with HPLC.

\subsection{In Vitro Biological Activity of Curcumin-Gold Nanoparticle}

\subsubsection{Cell Culture}

$\mathrm{NIH} / 3 \mathrm{~T} 3$ cells were cultured in medium containing High Glucose DMEM, 10\% fetal bovine serum, and $1 \%$ penicillin-streptomycin. The cells were incubated at $37{ }^{\circ} \mathrm{C}$ and $5 \% \mathrm{CO}_{2}$.

\subsubsection{Cytotoxic Assay}

Reagent from Promega ${ }^{\circledR}$ was used to determine the effect of curcumin, gold and cAuNPs on the viability of NIH/3T3 cells. Cells $\left(5 \times 10^{3}\right)$ were plated on 96-well plate before incubation at $37^{\circ} \mathrm{C}$ for $48 \mathrm{~h}$ with $5 \% \mathrm{CO}_{2}$. After incubation, the cell medium was replaced with a serum-free medium and incubated for $4 \mathrm{~h}$. Then, the samples $(50 \mu \mathrm{L})$ with various concentrations were added to the well and incubated for $24 \mathrm{~h}$. Dye solution was subsequently added to the well and incubated at $37^{\circ} \mathrm{C}$ with $5 \%$ $\mathrm{CO}_{2}$ for $4 \mathrm{~h}$. Lastly, stop solution was added and incubated for $1 \mathrm{~h}$. Cell absorbance was measured while using ELISA microplate reader at $570 \mathrm{~nm}$.

\subsubsection{Activity of cAuNPs on the Total Collagen}

Sample effect on the reduction of total collagen in NIH/3T3 cell was tested by using Sirius Red/Fast Green Staining kit. NIH/3T3 cells were grown on 6-well plate and incubated with curcumin, gold, and cAuNPs at $37{ }^{\circ} \mathrm{C}$, and $5 \% \mathrm{CO}_{2}$ for $24 \mathrm{~h}$. The medium was then removed, and the plate was washed with PBS solution. Kahle fixative was subsequently added into the cell and incubated for $10 \mathrm{~min}$ at room temperature, followed with the addition of the dye solution and incubation for $30 \mathrm{~min}$ at room temperature. Buffer extraction solution was then added, and cell absorbance was measured with UV-visible spectrophotometer at wavelength 540 and $605 \mathrm{~nm}$.

$$
\begin{gathered}
\text { Collagen }\left(\frac{\mu \mathrm{g}}{\text { well }}\right)=\frac{\mathrm{A}_{540}-\left(\mathrm{A}_{605} \times 0.291\right)}{0.0378} \\
\text { Non collagen protein }\left(\frac{\mu \mathrm{g}}{\text { well }}\right)=\frac{\mathrm{A}_{605}}{0.00204}
\end{gathered}
$$




\subsubsection{In Ovo Toxicity Test}

Fertilized eggs were stored vertically $30 \mathrm{~min}$ before sample injection. Sterilized $1 \mathrm{~mL}$ syringe with needle was used to create a hole through the eggshell and to inject the sample. Eggs were divided into five groups. The first, second and third groups were treated with cAuNPs 100, 200, and $300 \mu \mathrm{g} / \mathrm{mL}$, respectively. The fourth group received toluene as positive control, and the fifth group was negative control, which did not receive any treatment.

\subsubsection{Statistical Analysis}

Statistical analysis was performed with ANOVA technique using Prism 7. The data were obtained from three replicates and presented as mean \pm SEM. The statistical significance of the differences was evaluated with Bonferroni test for multiple comparisons; differences with a $p$-value of 0.05 or less were considered to be significant.

\section{Results}

cAUNPs were synthesized with a colloidal method, in which the gold salt solution was chemically reduced by the presence of curcumin as surface stabilizing compound. In addition, the peak shifting of curcumin solution to $541 \mathrm{~nm}$ in the UV-Visible spectrum confirmed the conjugation of curcumin and gold (Figure 1).

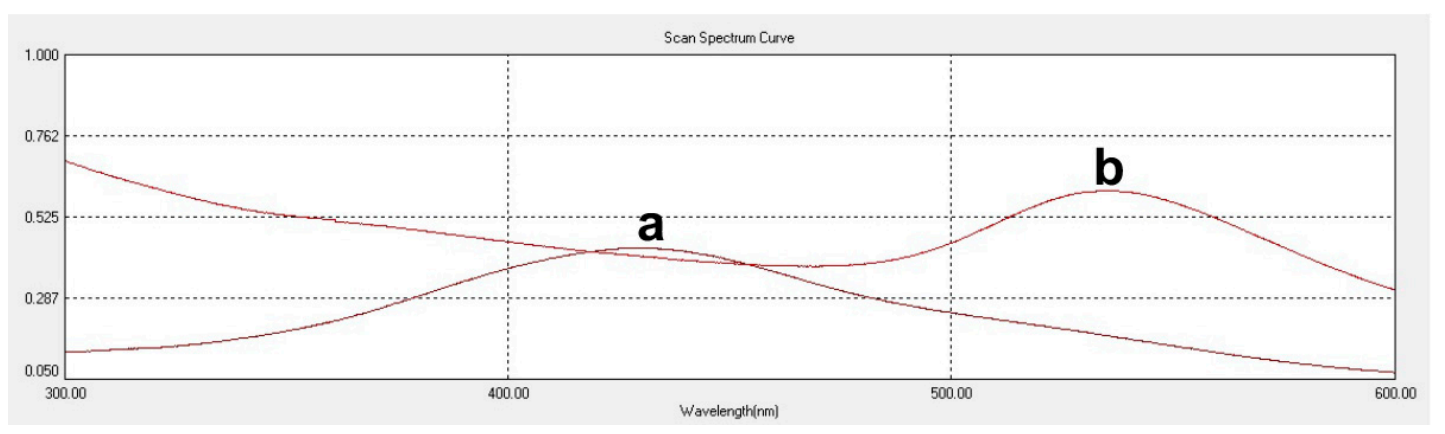

Figure 1. UV-VIS spectra of curcumin (a) and curcumin-gold nanoparticle (b).

Optimization of curcumin $\mathrm{pH}$ was based on the observation that there will not be any nanoparticle formation occurs by mixing the two solutions without changing the curcumin $\mathrm{pH}$ [26]. The absence of nanoparticle formation was observed in the curcumin at $\mathrm{pH} 8$, which was also observed at $\mathrm{pH} 10$ and 11 (Figure 2A). At pH 9.3, cAuNPs showed the highest intensity and narrow peak, indicating the abundance of produced nanoparticle and homogenous size distribution, respectively (Figure 2A).

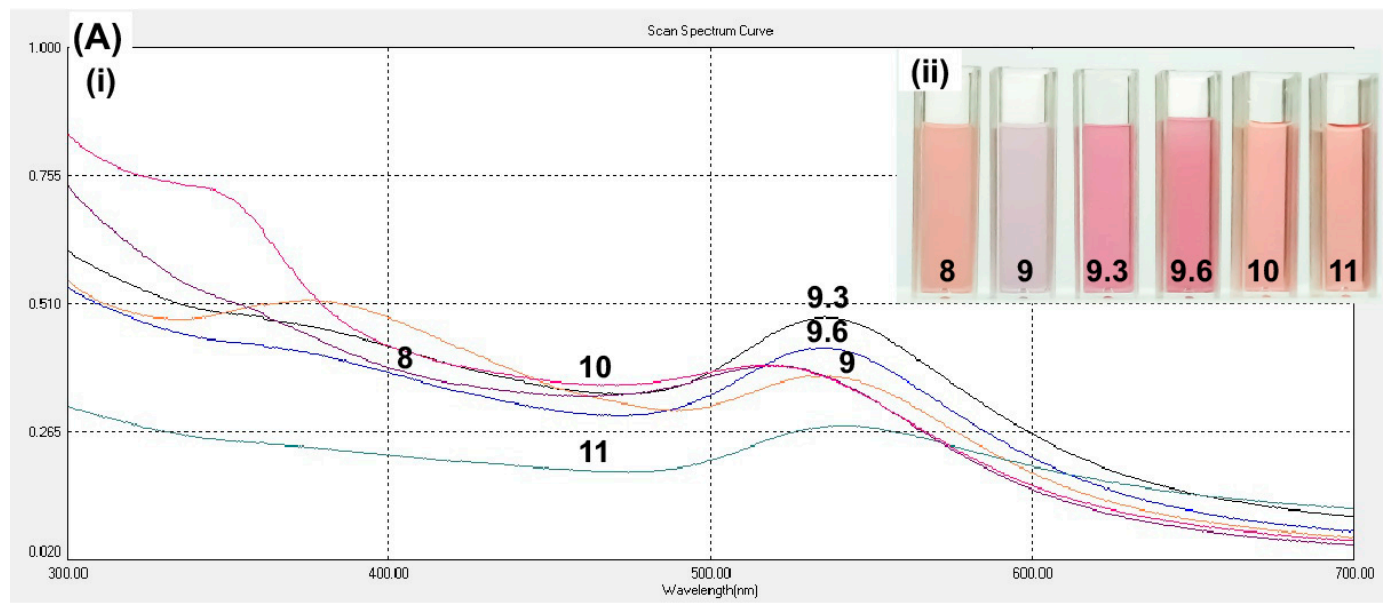

Figure 2. Cont. 


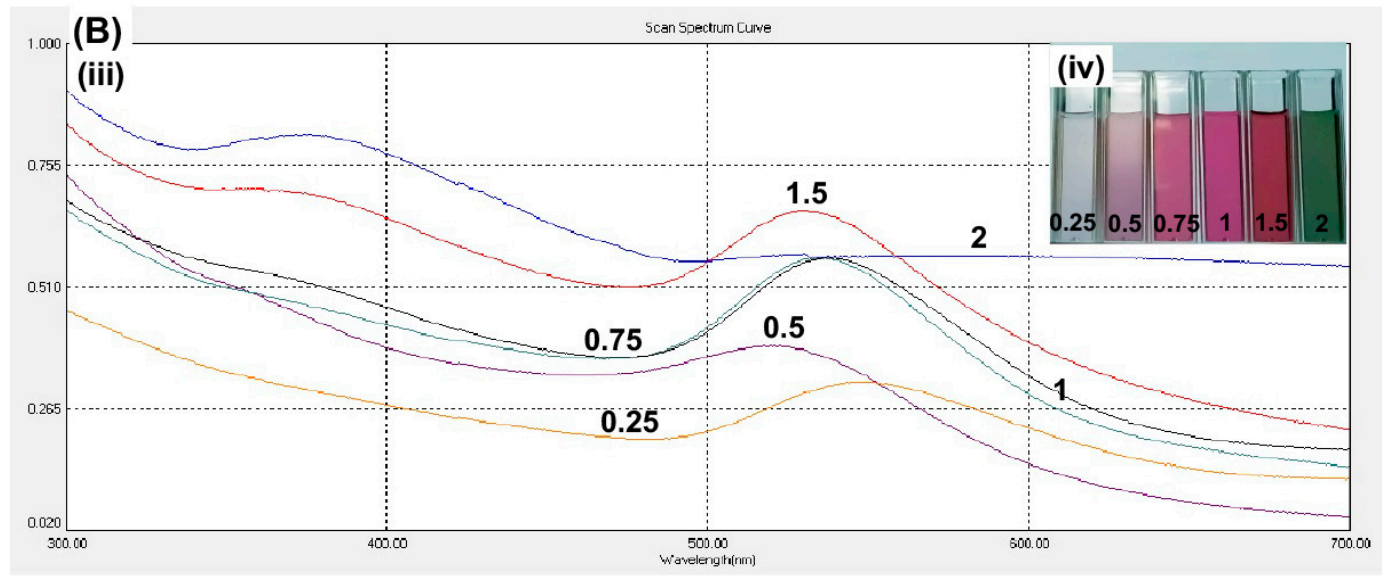

Figure 2. The UV-VIS spectra (i, iii) and solutions (ii, iv) of curcumin-gold nanoparticles at different $\mathrm{pH}$ of curcumin solution $(8,9,9.3,9.6,10$, and 11$)(\mathbf{A})$ and various concentrations of curcumin $(0.25,0.5$, $0.75,1,1.5$, and $2 \mathrm{mM})(\mathbf{B})$.

In addition, Table 1 showed that the desired range of size of nanoparticles $(<200 \mathrm{~nm})$ was obtained from curcumin with $\mathrm{pH} 8-10$. Nevertheless, the smallest size of the nanoparticles was obtained at $\mathrm{pH}$ 9.3. Hence, the curcumin at $\mathrm{pH} 9.3$ was chosen for further synthesis.

Table 1. Particle size of curcumin-gold nanoparticles obtained from different curcumin $\mathrm{pH}$ and concentration $(n=3)$.

\begin{tabular}{ccccccc}
\hline & \multicolumn{7}{c}{ Curcumin $\mathbf{~ H}$} \\
\cline { 2 - 7 } & $\mathbf{8}$ & $\mathbf{9}$ & $\mathbf{9 . 3}$ & $\mathbf{9 . 6}$ & $\mathbf{1 0}$ & $\mathbf{1 1}$ \\
\hline $\begin{array}{c}\text { Particle size (nm) } \\
\text { (Mean } \pm \text { SD) } \\
\begin{array}{c}\text { Polydispersity index } \\
\text { (Mean } \pm \text { SD) }\end{array}\end{array}$ & $103.0 \pm 10.8$ & $44.5 \pm 3.2$ & $41.2 \pm 1.8$ & $42.8 \pm 1.5$ & $71.9 \pm 3.3$ & $406.0 \pm 92.1$ \\
\hline & $0.41 \pm 0.12$ & $0.55 \pm 0.11$ & $0.29 \pm 0.07$ & $0.33 \pm 0.09$ & $0.41 \pm 0.04$ & $0.43 \pm 0.14$ \\
\cline { 2 - 7 } & $\mathbf{0 . 2 5}$ & $\mathbf{0 . 5}$ & $\mathbf{0 . 7 5}$ & $\mathbf{1}$ & $\mathbf{1 . 5}$ & $\mathbf{2}$ \\
\hline $\begin{array}{c}\text { Particle size (nm) } \\
\text { (Mean } \pm \text { SD) }\end{array}$ & $133.6 \pm 9.1$ & $119.1 \pm 6.5$ & $114.6 \pm 9.7$ & $112.2 \pm 4.3$ & $62.3 \pm 2.6$ & $374.4 \pm 9.1$ \\
$\begin{array}{c}\text { Polydispersity index } \\
\text { (Mean } \pm \text { SD) }\end{array}$ & $0.38 \pm 0.06$ & $0.35 \pm 0.03$ & $0.39 \pm 0.13$ & $0.36 \pm 0.08$ & $0.37 \pm 0.03$ & $0.67 \pm 0.11$ \\
\hline
\end{tabular}

Besides curcumin $\mathrm{pH}$, the curcumin concentration was optimized. A higher curcumin concentration will provide a greater density of the functional groups that are present in curcumin, which was expected to stabilize the gold and further decrease the nanoparticle size. The curcumin concentration of $1.5 \mathrm{mM}$ showed the highest spectrum intensity at the wavelength of $531 \mathrm{~nm}$ (Figure 2B). The higher concentration, $2 \mathrm{mM}$, did not show any signal at the wavelength $531 \mathrm{~nm}$ and the solution color was green (Figure 2B; inset). The solution of $0.25-1.5 \mathrm{mM}$ curcumin resulted in the size of particles within desired range of nanoparticles. However, $1.5 \mathrm{mM}$ curcumin produced the smallest size of nanoparticles (Table 1). Hence, we proceeded on the conjugation of curcumin and gold nanoparticle by using $1.5 \mathrm{mM}$ curcumin at $\mathrm{pH} 9.3$.

The infrared spectrum of curcumin showed bands at $1205.51 \mathrm{~cm}^{-1}, 1377.17 \mathrm{~cm}^{-1}$, and $962.48 \mathrm{~cm}^{-1}$, which represented the in-plane bending of the hydroxyl groups of two phenolic and an enolic group, respectively (Figure 3; red line). All three bands were completely absent in cAuNPs, which suggested the interaction of $\mathrm{AuHCl}_{4}$ at these sites (Figure 3; black line). The narrow-spaced doublet at $1627.92 \mathrm{~cm}^{-1}$ could be assigned to the symmetric stretching of the alkene conjugated to 1,3-diketone group, and the peak at $1508.33 \mathrm{~cm}^{-1}$ could be assigned to the stretching vibration of the aromatic ring 
(Figure 3; red line). After the stabilization of gold nanoparticles by curcumin, there is a shift in $\mathrm{C}=\mathrm{O}$ peak at $1625.99 \mathrm{~cm}^{-1}$ appearing as a broad band, towards a higher frequency (Figure 3; black line).

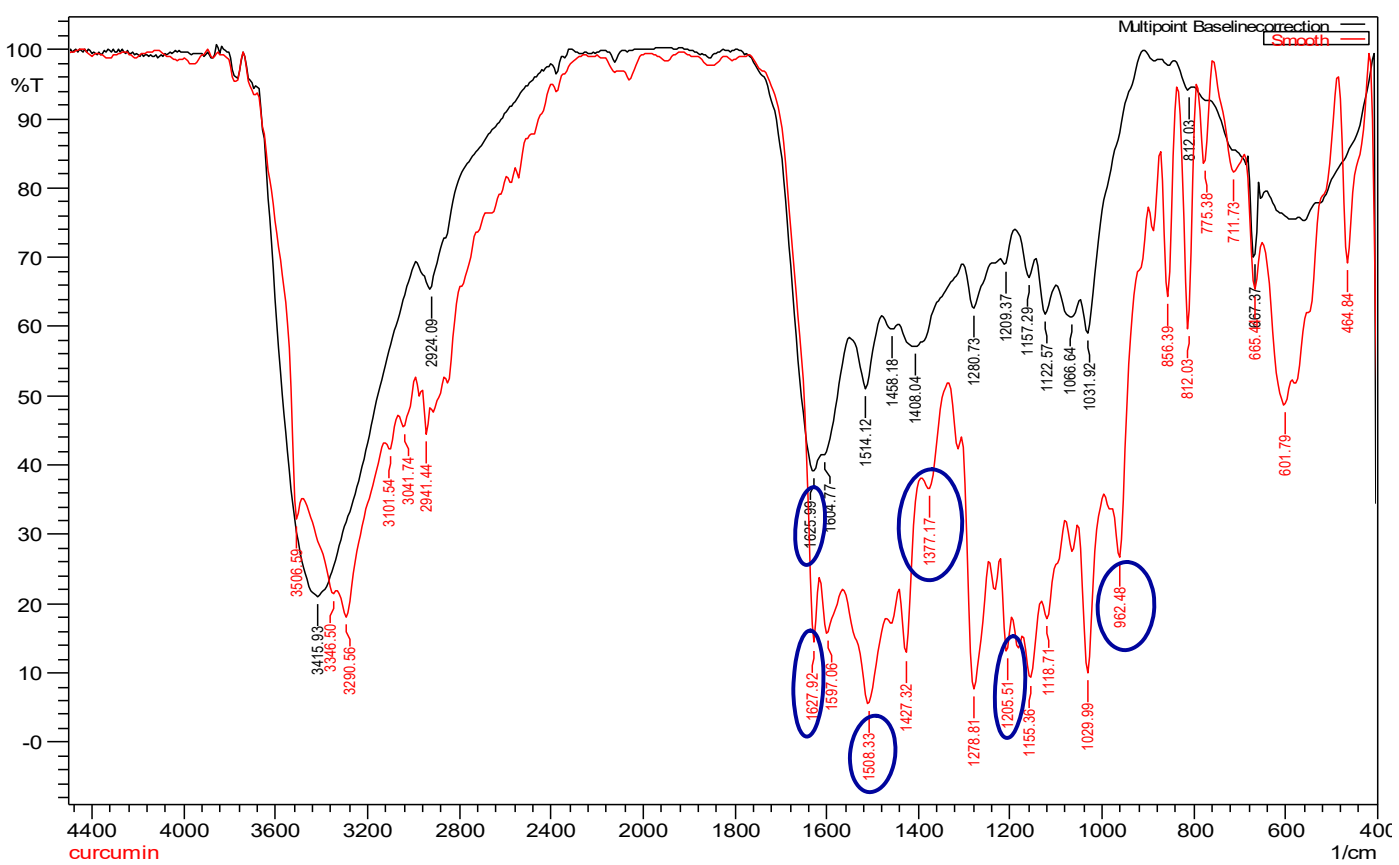

Figure 3. Infrared spectra of curcumin (red line) and curcumin-gold nanoparticle (black line).

The morphology and particle size of curcumin-gold nanoparticles was analyzed by using cryo-Transmission Electron Morphology (cryo-TEM). cAuNPs had predominantly spherical particles and their size corresponded to the desired particle size range from 50 to $200 \mathrm{~nm}$ (Figure 4). This result was in line with the particle size of cAuNPs that were measured while using particle size analyzer (Table 1).

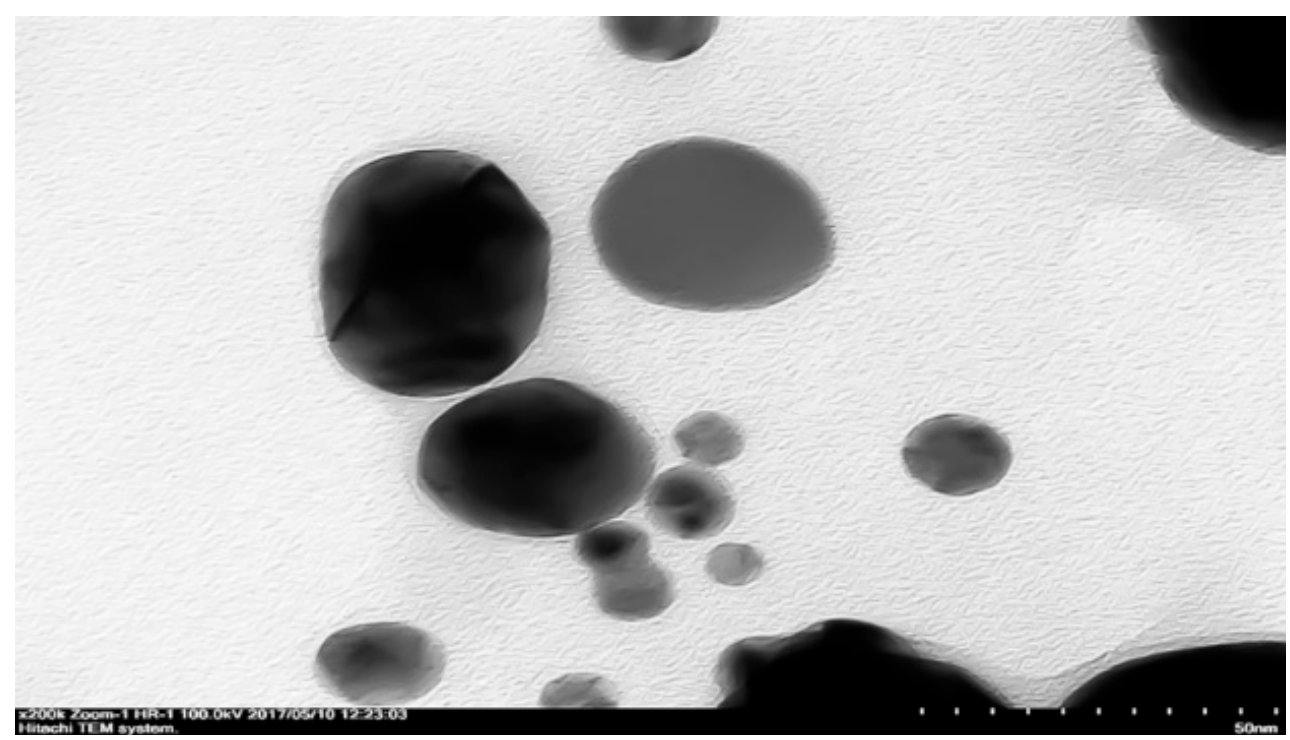

Figure 4. cryo-TEM image of curcumin-gold nanoparticle with 200,000 times magnification.

The antioxidant activity of cAuNPs was tested by using DPPH method, and ascorbic acid was used as positive control. cAuNPs, with the $\mathrm{IC}_{50}$ of $1.50 \pm 0.30$, showed the strongest antioxidant activity when compared to absorbic acid and other samples (Table 2). On top of that, the antioxidant activity of cAuNPs and gold nanoparticles were stronger than free curcumin. 
Table 2. $\mathrm{IC}_{50}$ of ascorbic acid, curcumin, gold, and curcumin-gold nanoparticles.

\begin{tabular}{cc}
\hline Sample & IC $_{\mathbf{5 0}}(\mu \mathrm{g} / \mathrm{mL})$ \\
\hline Ascorbic acid & $2.43 \pm 0.53$ \\
Curcumin & $5.59 \pm 0.22 *$ \\
Gold & $2.64 \pm 0.17^{\#}$ \\
Curcumin-gold nanoparticles & $1.50 \pm 0.30 *$, \\
\hline$n=3 * *<0.05$ compared to ascorbic acid. ${ }^{*} p<0.05$ compared to curcumin
\end{tabular}

The stability test of the cAuNPs was carried out at a temperature of $5^{\circ} \mathrm{C}$, room temperature $\left(25^{\circ} \mathrm{C}\right)$ and $40^{\circ} \mathrm{C}$ for one month. During a month storage, a slightly increased particle size was observed at $5{ }^{\circ} \mathrm{C}$ from $35.87 \pm 1.33 \mathrm{~nm}$ to $62.2 \pm 1.57 \mathrm{~nm}, 25^{\circ} \mathrm{C}$ from $35.87 \pm 1.33 \mathrm{~nm}$ to $53.43 \pm 1.31 \mathrm{~nm}$, and $40{ }^{\circ} \mathrm{C}$ from $35.87 \pm 1.33 \mathrm{~nm}$ to $53.37 \pm 3.43 \mathrm{~nm}$ (Figure 5).

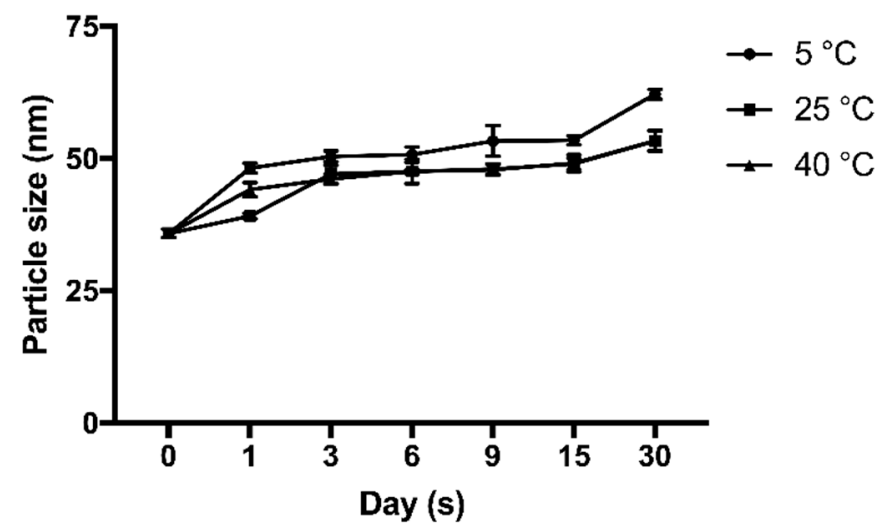

Figure 5. Particle size stability of cAuNPs at the $5{ }^{\circ} \mathrm{C}, 25^{\circ} \mathrm{C}$ and $40^{\circ} \mathrm{C}$ for 1 month $(n=3)$.

Furthermore, chemical stability of cAuNPs during a month storage was done at $5{ }^{\circ} \mathrm{C}, 25^{\circ} \mathrm{C}$, and $40{ }^{\circ} \mathrm{C}$. The concentration of curcumin in cAuNPs decreased by 12.36 and $12.88 \%$ at $5{ }^{\circ} \mathrm{C}$ and $25^{\circ} \mathrm{C}$, respectively (Figure 6A,B). The highest decreased curcumin concentration in cAuNPs was observed at $40{ }^{\circ} \mathrm{C}$, i.e., $29.64 \%$ (Figure $6 \mathrm{C}$ ). Nevertheless, free curcumin showed lower chemical stability when compared to curcumin in cAuNPs. Curcumin concentration decreased by $35.13,18.12$, and $39.55 \%$ at $5^{\circ} \mathrm{C}, 25^{\circ} \mathrm{C}$, and $40{ }^{\circ} \mathrm{C}$, respectively (Figure 6).

The effect of cAuNPs on the total collagen was determined with a semi quantitative method by using Sirius Red/Fast Green staining kit. Red cells were cells stained with Sirius Red and contained collagen proteins, while green cells were cells that contain non-collagen proteins and were stained with Fast Green. The cells morphology was observed prior to the measurement of cell absorbance. There was no significant difference in the morphology and the ratio of red or green-stained cells treated with curcumin, gold, and cAuNPs (Figure 7).

Based on the absorbance measurement of stained cells (Figure 7), curcumin, gold and cAuNPs can reduce the amount of collagen in NIH/3T3 cells significantly in a dose-dependent manner (Figure 8). However, cAuNPs at concentration of $0.25-1.5 \mu \mathrm{g} / \mathrm{mL}$ did not affect the viability of NIH/3T3 cells (Figure 9). While 1.25 and $1.5 \mu \mathrm{g} / \mathrm{mL}$ curcumin caused a significant decrease in cell viability of 3T3 cells to $48.96 \%$ and $44.06 \%$, respectively (Figure 9 ). 
(A)

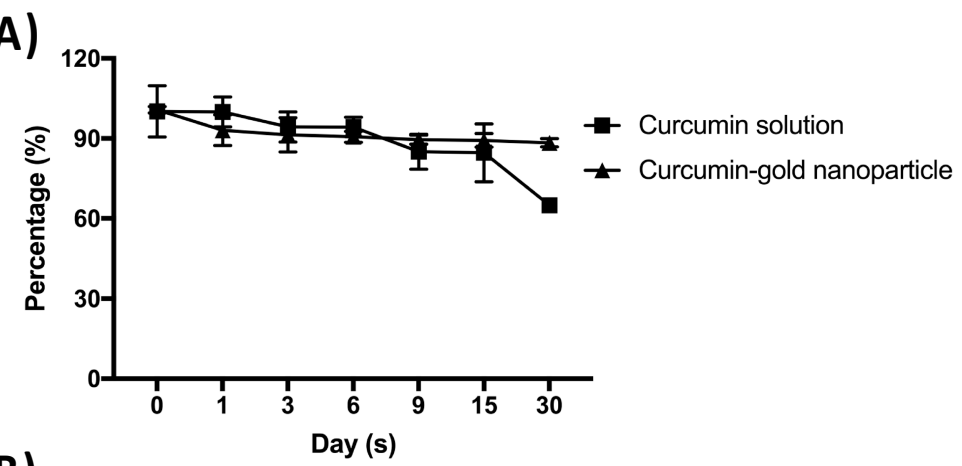

(B)

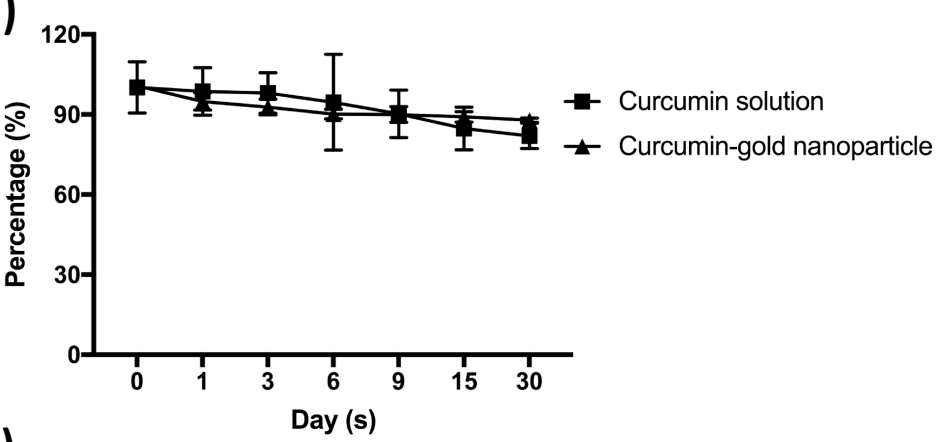

(C)

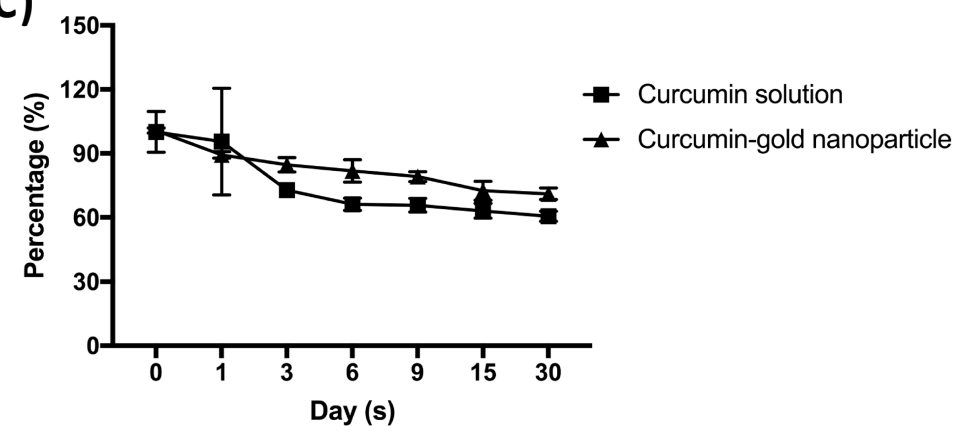

Figure 6. Curcumin and curcumin-gold nanoparticles concentration at $5{ }^{\circ} \mathrm{C}(\mathbf{A}), 25^{\circ} \mathrm{C}(\mathbf{B})$, and $40{ }^{\circ} \mathrm{C}$ (C) for 1 month.
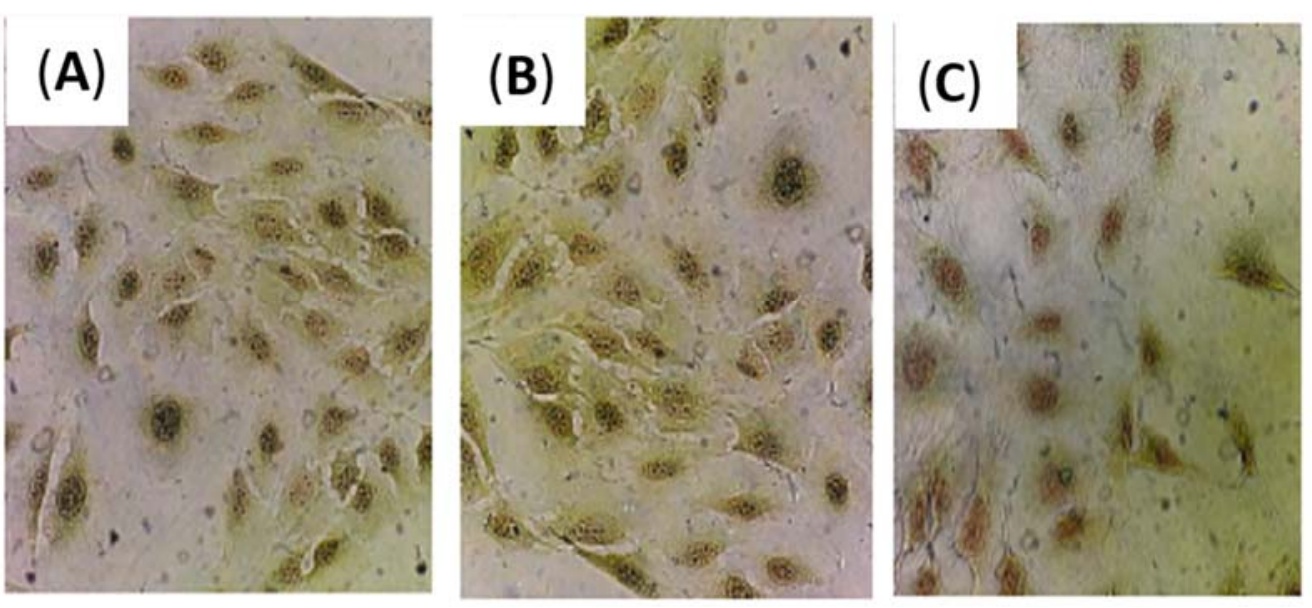

Figure 7. Morphology of NIH/3T3 cells after treated with curcumin (a), gold (b), and curcumin-gold nanoparticle (c). 


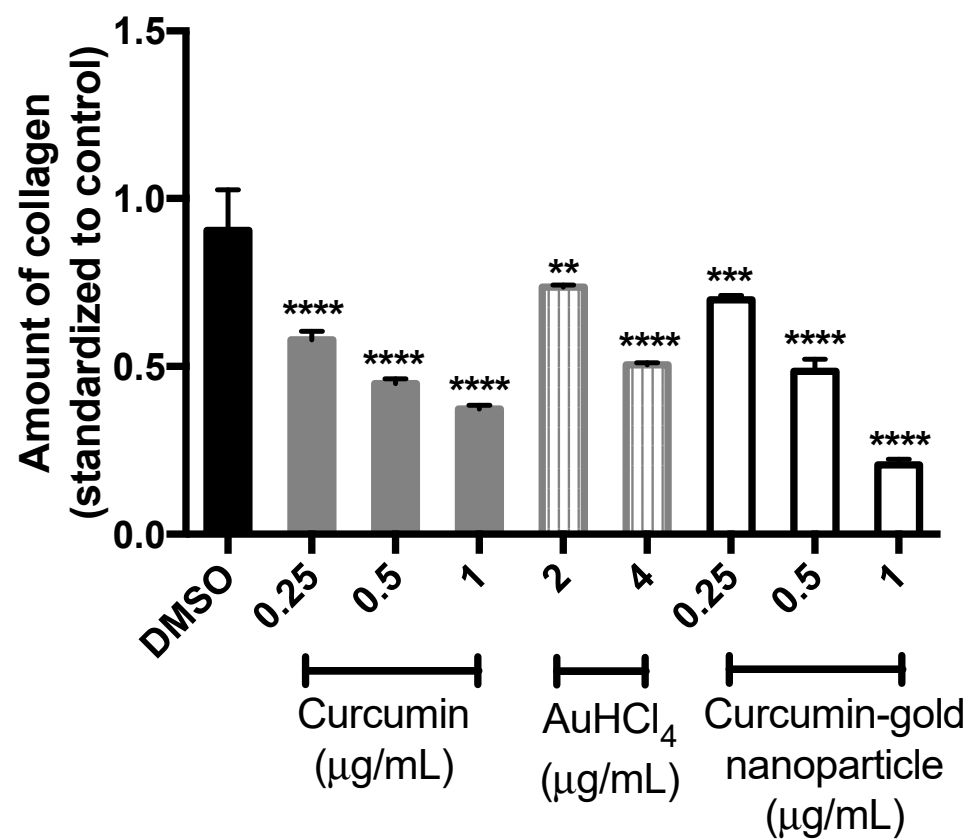

Figure 8. Effect of curcumin, $\mathrm{AuHCl}_{4}$, and curcumin-gold nanoparticles on the amount of collagen protein; $n=3 ;^{*} p \leq 0.05,{ }^{* *} p \leq 0.01,{ }^{* * *} p \leq 0.001,{ }^{* * *} p \leq 0.0001$.

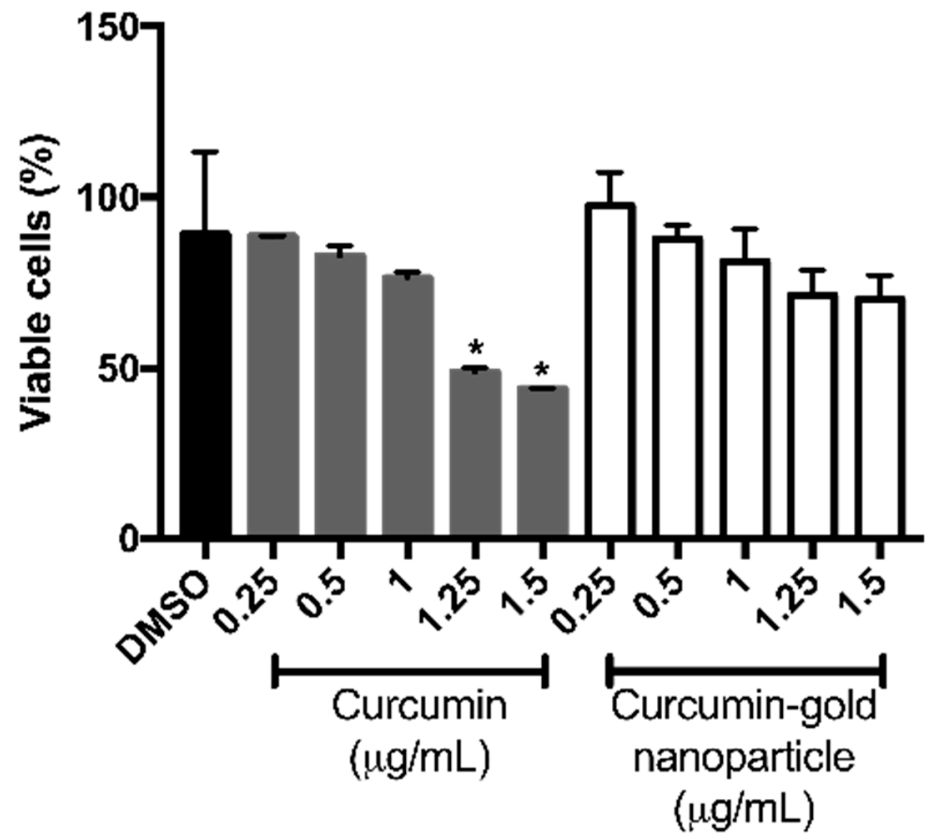

Figure 9. The viability of NIH/3T3 cells treated with curcumin and curcumin-gold nanoparticles at various concentrations. ${ }^{*} p \leq 0.05$.

In addition to the in vitro cytotoxicity test, an in ovo toxicity test of curcumin-gold nanoparticles was performed. The results showed that cAuNPs up to $300 \mu \mathrm{g} / \mathrm{mL}$ did not affect the development of chicken embryo (Figure 10). 


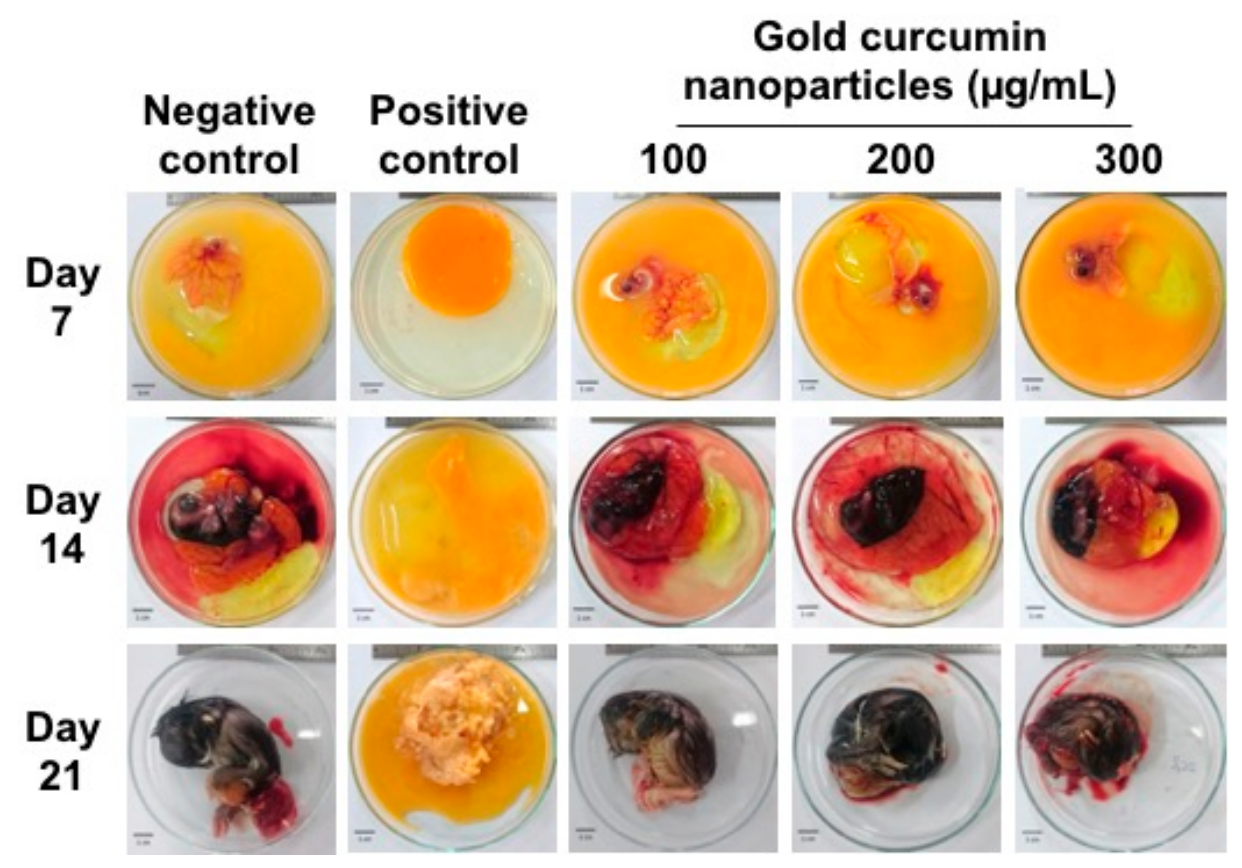

Figure 10. In ovo toxicity test of curcumin gold nanoparticles evaluated for 21 days. The chicken embryo were treated with 100,200 , and $300 \mu \mathrm{g} / \mathrm{mL}$ curcumin-gold nanoparticles. The positive control group was treated with toluene and the negative control group did not receive any treatment.

\section{Discussion}

The successful conjugation of curcumin and gold was visually identified through the color alteration of curcumin solution from yellow to pink. The color alteration occurred due to the reduction of particle size, which was caused by curcumin deprotonation where the hydrogen atoms are dissociated from the $-\mathrm{OH}$ groups of curcumin to form $\mathrm{Cur}^{3+}$ [26]. Subsequently, there was a reduction from $\mathrm{Au}^{3+}$ to $\mathrm{Au}^{0}$, followed by cluster formation by the $\mathrm{Au}^{0}$ atoms. The growth of the cluster led to instability, which was followed by cleaving to smaller fragments. The fragments were then stabilized by the ionized curcumin molecules, forming spherical, solid, and tight nanoparticles through processes, such as Ostwald ripening or intraparticle ripening [26].

The absence of cAuNPs formation at $\mathrm{pH} 8$ happened because curcumin is insoluble at $\mathrm{pH}$ below $9[34,35]$. As a consequence, curcumin was not able to reduce $\mathrm{Au}^{3+}$ to $\mathrm{Au}^{0}$. A higher $\mathrm{pH}$ creates charged molecules of curcumin, which can enhance its reducing and stabilizing ability [36]. However, curcumin is not stable at $\mathrm{pH} 10$ and 11, which caused the precipitation of cAuNps.

The color alteration that occurred during the synthesis indicates the growth of the clusters [26]. When the gold has not reacted yet with curcumin, the solution is colorless. The addition of curcumin caused the cluster to become larger, which was followed by the color alteration to purple [26]. When the nanoparticles were produced, the solution turned red. Increasing the amount of curcumin will stimulate the cluster growth, and the solution will turn green or black when the growth is uncontrollable [26]. In this study, the green colloid was observed in the cAuNPs, which was obtained from $2 \mathrm{mM}$ curcumin. In addition, the green colloid can happen because there was not enough $\mathrm{AuHCl}_{4}$ for the available curcumin causing a high amount of free curcumin in the system. Wang et al. [36] showed that free curcumin decomposed rapidly at higher $\mathrm{pH}$, which might explain the color difference in the cAuNPs that were produced from $2 \mathrm{mM}$ curcumin.

The absence of enolic and phenolic - $\mathrm{OH}$ groups of curcumin in the cAuNPs FTIR spectrum indicated the reduction of $\mathrm{Au}^{3+}$ by these groups and confirmed the conjugation of curcumin to gold. This result is in line with the FTIR spectrum of cAuNPs synthesized by using $\mathrm{K}_{2} \mathrm{CO}_{3}$ as $\mathrm{pH}$ adjuster [26].

The stronger antioxidant activity of cAuNPs proved that the conjugation of curcumin to gold nanoparticle in our study did not affect the antioxidant activity of curcumin. This is because 
gold particle also has antioxidant activity. A higher cAuNPs antioxidant activity was also shown by Singh et al. [31] by using different assays, i.e., superoxide dismutase and catalase assays. While Shaabani et al. [19] showed that the antioxidant activity of cAuNPs was higher than the gold nanoparticles synthesized by using sodium borohydride as reducing agent.

The physical stability test results showed a slightly increased size of cAuNPs after one month storage. Nevertheless, the size was still in the required range of nanoparticles, i.e., less than $100 \mathrm{~nm}$ [37]. The chemical stability test showed a decreased curcumin concentration in both free curcumin solution and cAuNPs after one month storage at all three temperatures. However, the decrease of curcumin concentration was higher in free curcumin solution when compared to curcumin in cAunPS. The reduction of curcumin concentration in cAuNPs can happen because of the alkaline $\mathrm{pH}$. Since our cAuNPs were synthesized at $\mathrm{pH}$ 9.3, the degradation of curcumin can occur during storage. Curcumin degrades to condensed products like ferulic acid and vanillin at alkaline $\mathrm{pH}$ [38]. To date, there is no study yet showing the chemical stability of curcumin in cAuNPs after more than one month storage. The previous studies on stability of cAuNPs only showed the physical characterization of stored cAuNPs and not the curcumin content $[24,26]$. Nevertheless, the decreased curcumin concentration in this study requires further investigation in order to improve the cAuNPs physical and chemical stability during storage.

The curcumin antifibrotic activity on inhibiting collagen synthesis by NIH/3T3 cells has been shown previously by our group [14]. The antifibrotic activity of curcumin might be due to its antioxidant and anti-inflammatory activity. It is known that oxidative stress has important role in hepatic fibrogenesis, particularly in the activation of hepatic stellate cells [16]. In this work, it was shown the curcumin antifibrotic activity was retained in the cAuNPs. Even better, cAuNPs did not affect the viability of NIH/3T3 cells, despite its antifibrotic activity. This means that cAuNPs is non-toxic when compared to free curcumin in cellular level. Low cytotoxicity level of drugs is necessary in the treatment of liver fibrosis to avoid the fibrosis progression due to the cell death that is caused by the drugs [39].

An in ovo toxicity test was conducted in this study to prove that cAuNPs was non-toxic in addition to the cytotoxicity test. Our results showed that cAuNPs up to $300 \mu \mathrm{g} / \mathrm{mL}$ did not affect the development of chicken embryo. This confirmed that cAuNPs are biocompatible, not only in cellular level, but also in a more complex biological environment.

To conclude, this study showed that attaching gold to curcumin improved the antioxidant activity of curcumin and preserved the NIH/3T3 cell viability at the concentration of $0.25-1.5 \mu \mathrm{g} / \mathrm{mL}$, followed by retained antifibrotic activity. In addition to its bioactivity improvement, the nanoparticle of curcumin-gold up was non-toxic. Further in vivo study is required to evaluate the targeting property of curcumin-gold nanoparticle to the liver.

Author Contributions: Conceptualization, H.R.; Data curation, I.T. and A.M.; Formal analysis, I.T., A.M., S.D. and H.R.; Funding acquisition, H.R.; Investigation, H.R.; Methodology, S.D.; Supervision, H.R.; Validation, S.D.; Writing — original draft, A.A.; Writing—review \& editing, A.A. and H.R.

Funding: This research received no external funding.

Acknowledgments: The work presented on this paper was partly funded by "Riset dan Inovasi ITB 2016".

Conflicts of Interest: The authors declare no conflict of interest.

\section{References}

1. Williams, R. Global challenges in liver disease. Hepatology 2006, 44, 521-526. [CrossRef] [PubMed]

2. Blachier, M.; Leleu, H.; Peck-Radosavljevic, M.; Valla, D.C.; Roudot-Thoraval, F. The burden of liver disease in Europe: A review of available epidemiological data. J. Hepatol. 2013, 58, 593-608. [CrossRef] [PubMed]

3. Cainelli, F. Liver diseases in developing countries. World J. Hepatol. 2012, 4, 66-67. [CrossRef] [PubMed]

4. Metrakos, P.; Nilsson, T. Non-alcoholic fatty liver disease-a chronic disease of the 21(st) century. J. Biomed. Res. 2017. [CrossRef] 
5. Wasley, A.; Alter, M.J. Epidemiology of hepatitis C: Geographic differences and temporal trends. Semin. Liver Dis. 2000, 20, 1-16. [CrossRef] [PubMed]

6. Mueller, S.; Millonig, G.; Seitz, H.K. Alcoholic liver disease and hepatitis C: A frequently underestimated combination. World J. Gastroenterol. 2009, 15, 3462-3471. [CrossRef] [PubMed]

7. Spengler, U. Direct antiviral agents (DAAs)—A new age in the treatment of hepatitis C virus infection. Pharmacol. Ther. 2018, 183, 118-126. [CrossRef] [PubMed]

8. Hayes, C.N.; Chayama, K. Why highly effective drugs are not enough: The need for an affordable solution to eliminating HCV. Expert Rev. Clin. Pharmacol. 2017, 10, 583-594. [CrossRef] [PubMed]

9. Stickel, F.; Schuppan, D. Herbal medicine in the treatment of liver diseases. Dig. Liver Dis. 2007, 39, $293-304$. [CrossRef] [PubMed]

10. Levy, C.; Seeff, L.D.; Lindor, K.D. Use of herbal supplements for chronic liver disease. Clin. Gastroenterol. Hepatol. 2004, 2, 947-956. [CrossRef]

11. Ferrucci, L.M.; Bell, B.P.; Dhotre, K.B.; Manos, M.M.; Terrault, N.A.; Zaman, A.; Murphy, R.C.; Vanness, G.R.; Thomas, A.R.; Bialek, S.R.; et al. Complementary and alternative medicine use in chronic liver disease patients. J. Clin. Gastroenterol. 2010, 44, e40-e45. [CrossRef] [PubMed]

12. Henson, J.B.; Brown, C.L.; Chow, S.C.; Muir, A.J. Complementary and Alternative Medicine Use in United States Adults with Liver Disease. J. Clin. Gastroenterol. 2017, 51, 564-570. [CrossRef] [PubMed]

13. Xu, J.Y.; Zhang, L.; Li, Z.P.; Ji, G. Natural Products on Nonalcoholic Fatty Liver Disease. Curr. Drug Targets 2015, 16, 1347-1355. [CrossRef] [PubMed]

14. Rachmawati, H.; Novel, M.A.; Nisa, R.M.; Berlian, G.; Tandrasasmita, O.M.; Rahma, A.; Riani, C.; Tjandrawinata, R.R. Co-delivery of curcumin-loaded nanoemulsion and Phaleria macrocarpa extract to NIH 3 T3 cell for antifibrosis. J. Drug Deliv. Sci. Technol. 2017, 39, 123-130. [CrossRef]

15. Yao, Q.; Lin, Y.; Li, X.; Shen, X.; Wang, J.; Tu, C. Curcumin ameliorates intrahepatic angiogenesis and capillarization of the sinusoids in carbon tetrachloride-induced rat liver fibrosis. Toxicol. Lett. 2013, 222, 72-82. [CrossRef] [PubMed]

16. Zhang, F.; Zhang, Z.; Chen, L.; Kong, D.; Zhang, X.; Lu, C.; Lu, Y.; Zheng, S. Curcumin attenuates angiogenesis in liver fibrosis and inhibits angiogenic properties of hepatic stellate cells. J. Cell. Mol. Med. 2014, 18, 1392-1406. [CrossRef] [PubMed]

17. Barta, A.; Janega, P.; Babal, P.; Murar, E.; Cebova, M.; Pechanova, O. The effect of curcumin on liver fibrosis in the rat model of microsurgical cholestasis. Food Funct. 2015, 6, 2187-2193. [CrossRef] [PubMed]

18. Zhao, Y.; Ma, X.; Wang, J.; He, X.; Hu, Y.; Zhang, P.; Wang, R.; Li, R.; Gong, M.; Luo, S.; et al. Curcumin protects against $\mathrm{CCl}$-induced liver fibrosis in rats by inhibiting HIF-1alpha through an ERK-dependent pathway. Molecules 2014, 19, 18767-18780. [CrossRef] [PubMed]

19. Shaabani, E.; Amini, S.M.; Kharrazi, S.; Tajerian, R. Curcumin coated gold nanoparticles: Synthesis, characterization, cytotoxicity, antioxidant activity and its comparison with citrate coated gold nanoparticles. Nanomed. J. 2017, 4, 115-125. [CrossRef]

20. Nath, D.; Banerjee, P. Green nanotechnology-A new hope for medical biology. Environ. Toxicol. Pharmacol. 2013, 36, 997-1014. [CrossRef] [PubMed]

21. De Jong, W.H.; Hagens, W.I.; Krystek, P.; Burger, M.C.; Sips, A.J.; Geertsma, R.E. Particle size-dependent organ distribution of gold nanoparticles after intravenous administration. Biomaterials 2008, 29, 1912-1919. [CrossRef] [PubMed]

22. Hoshyar, N.; Gray, S.; Han, H.; Bao, G. The effect of nanoparticle size on in vivo pharmacokinetics and cellular interaction. Nanomedicine 2016, 11, 673-692. [CrossRef] [PubMed]

23. Bednarski, M.; Dudek, M.; Knutelska, J.; Nowinski, L.; Sapa, J.; Zygmunt, M.; Nowak, G.; Luty-Blocho, M.; Wojnicki, M.; Fitzner, K.; et al. The influence of the route of administration of gold nanoparticles on their tissue distribution and basic biochemical parameters: In vivo studies. Pharmacol. Rep. 2015, 67, 405-409. [CrossRef] [PubMed]

24. Manju, S.; Sreenivasan, K. Gold nanoparticles generated and stabilized by water soluble curcumin-polymer conjugate: Blood compatibility evaluation and targeted drug delivery onto cancer cells. J. Colloid Interface Sci. 2012, 368, 144-151. [CrossRef] [PubMed]

25. Singh, D.K.; Jagannathan, R.; Khandelwal, P.; Abraham, P.M.; Poddar, P. In situ synthesis and surface functionalization of gold nanoparticles with curcumin and their antioxidant properties: An experimental and density functional theory investigation. Nanoscale 2013, 5, 1882-1893. [CrossRef] [PubMed] 
26. Sindhu, K.; Rajaram, A.; Sreeram, K.J.; Rajaram, R. Curcumin conjugated gold nanoparticle synthesis and its biocompatibility. RSC Adv. 2014, 4, 1808-1818. [CrossRef]

27. Masson, M.J.; Carpenter, L.D.; Graf, M.L.; Pohl, L.R. Pathogenic role of natural killer T and natural killer cells in acetaminophen-induced liver injury in mice is dependent on the presence of dimethyl sulfoxide. Hepatology 2008, 48, 889-897. [CrossRef] [PubMed]

28. Priyadarsini, K.I. Photophysics, photochemistry and photobiology of curcumin: Studies from organic solutions, bio-mimetics and living cells. J. Photochem. Photobiol. C Photochem. Rev. 2009, 10, 81-95. [CrossRef]

29. Sreelakshmi, C.; Goel, N.; Datta, K.K.R.; Addlagatta, A.; Ummanni, R.; Reddy, B.V.S. Green Synthesis of Curcumin Capped Gold Nanoparticles and Evaluation of Their Cytotoxicty. Nanosci. Nanotechnol. Lett. 2018, 5, 1258-1265. [CrossRef]

30. Gangwar, R.K.; Dhumale, V.A.; Kumari, D.; Nakate, U.T.; Gosavi, S.W.; Sharma, R.B.; Kale, S.N.; Datar, S. Conjugation of curcumin with PVP capped gold nanoparticles for improving bioavailability. Mater. Sci. Eng. C 2012, 32, 2659-2663. [CrossRef]

31. Singh, L.M.; Chakraborty, B.; Pal, R.; Nath, A.; Pal, S.; Rahman, D.S.; Ghosh, S.K.; Sengupta, M. A comparative study on the antioxidant and immunomodulatory properties of curcumin conjugated gold nanospheres and free curcumin. J. Appl. Pharm. Sci. 2017, 7, 2231-3354. [CrossRef]

32. Farzaneh, M.; Attari, F.; Khoshnam, S.E.; Mozdziak, P.E. The method of chicken whole embryo culture using the eggshell windowing, surrogate eggshell and ex ovo culture system. Br. Poult. Sci. 2018, 59, 240-244. [CrossRef] [PubMed]

33. Blois, M.S. Antioxidant Determinations by the Use of Stable Free Radical. Nature 1958, 181, 1199-1200. [CrossRef]

34. Tonnesen, H.H.; Masson, M.; Loftsson, T. Studies of curcumin and curcuminoids. XXVII. Cyclodextrin complexation: Solubility, chemical and photochemical stability. Int. J. Pharm. 2002, 244, 127-135. [CrossRef]

35. Tonnesen, H.H. Solubility, chemical and photochemical stability of curcumin in surfactant solutions. Studies of curcumin and curcuminoids, XXVIII. Pharmazie 2002, 57, 820-824. [PubMed]

36. Wang, Y.J.; Pan, M.H.; Cheng, A.L.; Lin, L.I.; Ho, Y.S.; Hsieh, C.Y.; Lin, J.K. Stability of curcumin in buffer solutions and characterization of its degradation products. J. Pharm. Biomed. Anal. 1997, 15, 1867-1876. [CrossRef]

37. Laurent, S.; Forge, D.; Port, M.; Roch, A.; Robic, C.; Vander Elst, L.; Muller, RN. Magnetic iron oxide nanoparticles: Synthesis, stabilization, vectorization, physicochemical characterizations, and biological applictions. Chem. Rev. 2008, 108, 2064-2110. [CrossRef] [PubMed]

38. Leung, M.H.; Colangelo, H.; Kee, T.W. Encapsulation of curcumin in cationic micelles suppresses alkaline hydrolysis. Langmuir 2008, 24, 5672-5675. [CrossRef] [PubMed]

39. Wang, K. Molecular mechanisms of hepatic apoptosis. Cell Death Dis. 2014, 5, e996. [CrossRef] [PubMed] 